\title{
Researching the Morlachs and the Uskoks \\ The Challenges of Writing about Marginal People from the Border Region of Dalmatia (Sixteenth Century)
}

\author{
DANA CACIUR \\ Nicolae Iorga Institute of History, Bucarest
}

In the narrow strip of Venetian Dalmatia, the official peace that characterised the middle of the sixteenth century ${ }^{1}$ paved the way for encounters between people, ideas and interests. ${ }^{2}$ The agents ${ }^{3}$ of the Christian and Islamic powers that shared the mountainous border of the province also developed ways and means to benefit from the new political status of the area and, more importantly, to assure their survival. The term 'agents' used in the context of sixteenth-century Dalmatia refers to those individuals spurred into action by the diplomacy required by the shifting border ${ }^{4}$ shared between the Republic of Venice and the Ottoman Empire, and, unrelated to political decisions, by the daily activities of the coexisting subjects. ${ }^{5}$ When researching

1 The peace concluded in October 1540 marked the end of the Venetian-Ottoman war of 1537-40. This war caused the loss of two important strongholds (Nadin and Vrana) in the hinterland of Dalmatia and introduced the area to instability, depopulation and the constant threat of Ottoman offensives.

2 These encounters, however unavoidable, with which Venice was already familiar given its experience in other provinces of the Stato da Mar, are summed up by the sources under the phrase per vicinar bene. This idea of a good neighbourhood, friendship and collaborations between the people of Venice and those of the Ottoman Empire was officially stipulated in the texts of the peace agreements beginning with that of 1479, published in English in DiAnA GILliLAND WrighT and PIERreA. MacKaY, 'When the Serenissima and the Gran Turco Made Love: The Peace Treaty of 1478,' Studi Veneziani 53 (2008): 261-77. The policy of neighbourliness underlined the reciprocal help in protecting those subjects who crossed the shared border areas, the protection of local trade and traders, and the restitution of fugitives and redeemed slaves.

${ }^{3}$ For more about this concept see NoEl Malcolm, Agents of Empire: Knights, Corsairs, Jesuits and Spies in the Sixteenth-Century Mediterranean World (London: Allen Lane-Penguin Random House, 2015), XVII. The 'full spectrum of interactions between Christians and Ottomans' can also involve entire social groups that could carry goods, information, cultural features, ideas or customs from one side to the other, or whose activities could influence the socio-political and economic life of an area of intersection. The Morlachs and Uskoks present in the border area of Venetian Dalmatia acted as smaller agents who were nevertheless equally important for the functioning of relations between the great powers.

${ }^{4}$ The concept of border was understood as a larger area and not as a clearly defined frontier line; see Maria Pia Pedani, The Ottoman-Venetian Border (15th-18th Centuries) (Venice: Edizioni Ca' Foscari Digital Publishing, 2017).

${ }^{5}$ Nora Berend, At the Gate of Christendom: Jews, Muslims and 'Pagans' in Medieval Hungary, c.1000-c.1300 (Cambridge: Cambridge University Press, 2001), 3: 'coexistence is not an attempt to refer to some golden age of harmonious tolerant interaction [...] It subsumes both peaceful and hostile relations, until the eradication of the minorities, either by assimilation or expulsion.'

Cromohs (Cyber Review of Modern Historiography), ISSN 1123-7023, 23/2020

(C) 2020 The Authors. This is an open access article published by Firenze University Press under the terms of the Creative Commons Attribution Licence, which permits use, distribution and reproduction in any medium, provided the original work is properly cited DOI: $10.36253 /$ cromohs-12193 
the idea of transimperial ${ }^{6}$ cross-border agency, one might feel tempted to focus firstly on the political/administrative figures who were in charge of maintaining the good relations established through peace agreements or other treaties (on commerce, ransoms, passages, etc.). However, similarly to many other border areas, ${ }^{7}$ the rural hinterland of Dalmatia became a space where different types of agents assured exchanges across groups. ${ }^{8}$ The resulting mixture ${ }^{9}$ convinced eighteenth-century Western travellers to describe the province as the gate towards the wild Europe. ${ }^{10}$ As immigrants, refugees, merchants, shepherds, criminals or soldiers, these others challenged locals and authorities to find solutions for their inclusion or removal, in order to avoid territorial losses and any complications to everyday life in the over-sea province of Venice. $^{11}$

Of the agents of coexistence in Dalmatia, the Morlachs and Uskoks were considered by far the most 'exotic' and curious. The chosen descriptive words (exotic and curious) are appropriate if we take into consideration that neither the large bibliography dedicated to them, nor the immense quantity of documents mentioning

\footnotetext{
${ }^{6}$ E. Natalie Rothman, Brokering Empire: Trans-Imperial Subjects Between Venice and Istanbul (Ithaca, NY and London: Cornell University Press, 2012), 10-11. The explanation of 'trans-imperial subjects' offered by the author also applies to the case of the Morlachs and the Uskoks. Both these populations entered the Venetian space, became aware of the rules and functioning of the state, but only respected them insofar as they fulfilled their personal interests.

7 Relevant examples can be found in GÁBOr KÁRmán and LOVRO KunČEVIĆ, eds, The European Tributary States of the Ottoman Empire in the Sixteenth and Seventeenth Centuries (Leiden and Boston: Brill, 2013); GÁBOR KÁRMÁN, ed., Tributaries and Peripheries of the Ottoman Empire (Leiden: Brill, 2020); LIVIU PILAT and OVIDIU CRISTEA, eds, The Ottoman Threat and Crusading on the Eastern Border of Christendom during the 15th Century (Leiden and Boston: Brill, 2017).

8 PEDANI, The Ottoman-Venetian Border, 50: 'if marking peace sometimes employed a temporary cessation of the hostilities, marking a border by mutual consent meant corroborating an agreement that had to last for a very long period, without taking into consideration what theories and religions asserted.'

9 PeDANI, The Ottoman-Venetian Border, 33: 'customary stereotypes of a society of the frontier,' which also apply to the characters in my research: 'It is usually a male environment [...]; the living conditions are violent; killings and heinous crimes are committed in the name of religion (or profit or the necessity to appropriate someone else's space). Also heroic and savagely romantic characters, however, belong to this category of men: spurred by an ideal drive, they fight against the enemy - the hostile nature or a people different as for religion, culture and origin.'

${ }^{10}$ ANDrEI PIPPIDI, 'Naissance, renaissances et mort du Bon Sawvage. Àpropos de Morlaques et de Valaques,' Cabiers roumains d'etudes littéraires 2 (1979): 55-75; LARRY WOLFF, Venice and the Slavs: The Discovery of Dalmatia in the Age of Enlightenment (Stanford: Stanford University Press, 2001); GILBERTO PiZzAmiglio, 'La Dalmazia tra viaggio e romanzo: da Alberto Fortis a Giustiniana Wynne,' in Questioni Odeoporiche. Modelli e momenti del viaggio adriatico, eds GIOvanna SCIANATICO and RAFFAELE RUGGIERO (Bari: Palomar, 2007), 353-69; BOŽIDAR JEZERNIK, Europa selvaggia. I Balcani nello sguardo dei viaggiatori occidental (Turin: EDI, 2010), 6-8.

11 Daniel GofFman, The Ottoman Empire and Early Modern Europe (Cambridge: Cambridge University Press, 2002), 10-11: 'Societies promptly accommodated whichever state ruled over them, warriors crept back and forth across a divide that proved remarkably porous, and, surprisingly, that great segregator religion itself slipped into a latitudinarianism that facilitated borderland communication and even sometimes blurred the distinction between Christianity and Islam'; 18-19: 'rather than the government assuming the lead, Ottoman subjects and foreigners residing in Mediterranean port cities and along Balkan borderlands intensified their dialogues and carved out commercial and social enclaves along the Ottoman frontiers.'
} 
their names can answer the question of who they were. The present paper aims to emphasise some of the working hypotheses built up while researching sixteenthcentury Venetian documents. The analysis will highlight the diversity of sources and contexts which mention the Morlachs and Uskoks, discussed in relation to the Morlachs.

\section{Traditional Definitions}

The Morlachs of Dalmatia, as referred to in Venetian documents from the fifteenth century onwards, are usually defined as a heterogeneous and extremely mobile population of Vlach origin. Concerning the origin of their name, two theories are discussed. The first one is based on the explanations offered by Johannes Lucius ${ }^{12}$ and the text of Presbiter Diocleatus ${ }^{13}$ which he published and promoted. According to Lucius's text the name Morlach has its origins in Byzantium, in the Greek word Maurovlachus meaning 'the Black Latins.' The use of this name was explained as a choice made by the Venetians in order to differentiate them from the White Latins, who were thought to be inhabitants of the former Roman cities situated on the Adriatic coast. This theory is commonly used by scholars who understand the Morlachs as remnants of the Latinised/Romanised people from all over the Balkans. This theory has also had a strong echo in Romanian ${ }^{14}$ historiography since it suggested the fact that the Byzantine term Maurovlachus was used to identify Vlachs akin to those living in historic Moldavia. ${ }^{15}$ However popular and convenient this

\footnotetext{
12 Johannes LuCius, De regno Dalmatiae et Croatiae, libri sex, editio nova atque emendate (Vienna: Trattner, 1758).

13 The edition republished by Johannes GeOrgius SCHWANDTNER, Scriptores rerum Hungaricarum, Dalmaticarum, Croaticarum et Sclavonicarum, veteres ac genuine, tome III (Vienna: Kraus, 1748), 476-508.

${ }_{14}$ AdOLF ARMBruster, Romanitatea românilor. Istoria unei idei (Bucharest: Editura Enciclopedică, 1993); ANCA TANAŞOCA and NICOLAE-ŞERBAN TANAŞOCA, Unitate Romanică şi diversitate balcanică (Bucharest: Editura Fundației Pro, 2004); GHEORGHE ZBucheA, Românitatea sud-dunăreană (Bucharest: Editura Fundației PRO, 2014); DIMITRIE GĂZDARU, 'Numele etnice ale istro-românilor,' in Buletinul Institutului de Filologie Română, 1 (1934), 33-62; BOGDAN PETRICEICU HAŞDEU, Istoria critică a românilor, pământul Țării Românești, I (Bucharest: Tipografia Curții, 1874); T. HAGI-GOGU, Romanus și Vlachus sau ce este romanus, roman, român, aromân, valah și vlah (Bucharest: Tiparul Universitar, 1939); PETRE Ș. NĂSTUREL, 'Vlaho-Balcanica,' in Petre S. Năsturel. Études d'bistoire byzantine et post-byzantine, eds EMANUEL CONSTANTin ANTOCHe, Lidia Cotovanu, IOnu-AlexAndru Tudorie (Brăila: Istros - Muzeul Brăilei 'Carol I', 2019) 147-72; Silviu Dragomir, Vlabii din Nordul Peninsulei Balcanice în Evul Mediu, (Bucharest: Editura Academiei Române, 1959); SILVIU DrAgomir, Vlabii și Morlacii. Studiu din istoria românismului balcanic (Cluj: Imprimeria Bornemisa, 1924); SILVIU DRAGOMIR, 'Originea coloniilor române din Istria,' in Memoriile Secțiunii Istorice 3, no. 2 (1924): 201-31; SILVIU DraGOMIR, 'Vlahii din Serbia în sec. XII-XV', in Anuarul Institutului de Istorie Națională din Cluj 1 (1921-1922), 279-99.

15 The fragment of interest can be found in LuCIUS, De regno Dalmatiae et Croatiae, 284: ... posteriorbus autem temporibus eiusdem Valachiae trans istriana e partem majorem (nunc Moldaviam dictam) Maurovlabiam dixere Graeci ut Codinus testator. [in those times Wallachia beyond Danube and the upper parts (named Moldavia) were named by the Greeks Maurovlahiam, as Codinus testifies].
} 
theory is, it should be questioned since new research has contested the authenticity of the text written by Presbiter Diocleatus. ${ }^{16}$

The other theory regarding the origin of the Morlachs' name is a more regional one. According to it, the term 'Morlach' designated the Vlachs near the sea, as it resulted from joining the Serbo-Croatian words more (sea) and vlach. This theory can be suggested by the Croatian historiography of the previous centuries, supporting the argument that all the Romanic Vlachs had disappeared and all the remaining Vlachs were Slavic speakers. ${ }^{17}$

The discussion of the historiography of the Morlach name could be a life-long research topic on its own, given the number of published studies and the passions it usually provokes. However, my intention is not to embark on such an endeavour, but to focus on new archival material limited to a short period of time (the middle of the sixteenth century, between the war of 1537-1540 and the War of Cyprus of 15701573 ) in order to understand what lay behind the activities developed by the Morlachs. ${ }^{18}$

In the case of the Uskoks, the situation is a little clearer. Their name originates in the Serbo-Croatian word uskok meaning 'fugitive' ('the one who jumped in'; as well as the Croatian verb uskociti, 'to jump from one side to another,' with the Latin equivalent scoco). ${ }^{19}$ It is usually connected with their transfer, after the Ottoman conquest of Bosnia, from Ottoman lands towards Klis/Clissa, and later, in 1537, from Klis to Senj/Segnain in the North of Dalmatia. Over time, according to their activities, the name also came to be associated with words like: pirate, deserter, run-

16 Solange Bujan, 'La Chronique du prêtre de Dioclée. Un faux document historique,' Revue des études byzantines 66 (2008): 5-38; STEFAN TrajKOviĆ-FILIPOVIĆ, 'Inventing a Saint's Life: Chapter XXXVI of the Annals of a Priest of Dioclea,' Revue des études byzantines 71 (2013): 259-76.

17 Jovan Cvijić, La Péninsule balkanique: géographie humaine (Paris: Librairie Armand Colin, 1918), $358-$ 59. The topic is extensively discussed by SIMA ĆIRCKOVIĆ, The Serbs, trans. by Vuk Tošić (Oxford: Blackwell Publishing, 2004), 25-27 and further; CATHIE CARMiCHAEL, Ethnic Cleansing in the Balkan: Nationalism and the Destruction of Tradition (London and New York: Routledge, 2002), 96; WoLFF, Venice and the Slavs; LARRY WOLFF, 'Disciplinary Administration and Anthropological Perspective in Venetian Dalmatia: Official Reflections on the Morlacchi from the Peace of Passarowitz to the Grimani Reform,' in Constructing Border Societies on the Triplex Confinium, eds DRAGO ROKSANDIĆ et al. (Budapest: Central European University Budapest, 2000), 48-49; Drago ROKSANDiĆ, 'The Dinaric Vlachs/Morlachs in the Eastern Adriatic from the Fourteenth to the Sixteenth Centuries: How Many Identities?' in Balcani Occidentali, Adriatico e Venezia fra XIII e XVIII secolo / Der westliche Balkan, de Adriarum und Venedig (13.-18. Jahrbundert), eds GHERARdo OrTalli and Oliver Jens SCHMitT (Venice and Vienna: Verlag der Österreichischen Akademie der Wissenschaften, 2009), 271-85.

${ }^{18}$ In this respect the research developed by Tea Mayhew was also helpful. Her studies offer examples of case studies for a later period and also a methodology to follow: TEA MAYHEW, Dalmatia Between Ottoman and Venetian Rule: Contado di Zara, 1645-1718 (Rome: Viella, 2008); TEA MAYHEW, 'Soldiers, Widows and Families: Social and Political Status of the Professional Warriors of the Venetian Republic (1645-1718),' in Professions and Social Identity: New European and Historical Research, Gender and Society, ed. BerTeKe WAALDIJK (Pisa: Edizioni Plus-Pisa University Press, 2006), 89-101. Also, STEPHAN KARL SANDER-FAES, Urban Elites of Zadar: Dalmatia and the Venetian Commonwealth (15401569) (Rome: Viella, 2013).

19 MinUCi MinuCiO and PAOlO SARPI, Storia degli Uscochi, Co'i progressi di quella gente fino all'anno 1602 (Venice: Roberto Meietti, 1676), 2. 
away, criminal, thief, merciless person, etc. Hence, its use strongly suggests that uskok was a term used to identify a social group composed of individuals of different geographic origin, political patronage and social condition. ${ }^{20}$

\section{The Sources}

In the case of the Morlachs living in Dalmatia during the sixteenth century, approximating the number of sources mentioning them is a challenging task. The difficulty lies not only in the large number of documents kept in various archives around the Adriatic, and elsewhere, but also in the fact that they are scattered across various fonds in these archives. Hitherto in my research I have used published documents $^{21}$ and sources I found in the State Archives of Venice and the State Archives of Zadar. The cases in which the Morlachs could be found with the help of the indexes or other archival instruments were very few. Instead, most of the references were identified by reading page after page of the files from many of the archival collections relevant to the history of the Stato da Mar, Dalmatia and the activity of the Venetian ambassadors and other representatives. Hence, the collections in which I found mentions of the Morlachs are: Senato Deliberazioni Mar (both in the registers and the filze), ${ }^{22}$ Senato Deliberazioni Secrete ${ }^{23}$ (also in the registers and the filze), Bailo a Costantinopoli, ${ }^{24}$ Lettere e scritture turchesche, ${ }^{25}$ Capi de Consiglio de' Dieci, ${ }^{26}$ Consiglio de' Dieci, Collegio. Lettere secrete, ${ }^{27}$ Commemoriali, ${ }^{28}$ Avogaria di Comun, ${ }^{29}$ Senato Deliberazioni Costantinopoli (registers and filse), ${ }^{30}$ and Miscellanea materie miste e notabile. ${ }^{31}$ To these I added some files from the archives of Zadar: Opčina Trogir, ${ }^{32}$ Opčina Šibenik, ${ }^{33}$ Zadarski Knez, ${ }^{34}$ and

${ }^{20}$ Catherine Wendy Bracewell, The Uskos of Senj: Piracy, Banditry, and the Holy War in the Sixteenthcentury Adriatic (Ithaca and London: Cornell University Press, 2011); SvETKA ŠmiTRAN, Gli Uscocchi: Pirati, ribelli, guerrieri tra gli imperi ottomano e asburgico e la Repubblica di Venezia (Venice: Marsilio Editore, 2008); PhilliP LONGWORTH, 'The Senj Uskoks reconsidered,' Slavonic \& East European Review 57, no. 3 (1979) 348-68.

21 ŠIMEON LJuBIĆ, ed., Commissiones et relationes Venetae, II (1525-1553) (Zagreb: Officina Societatis Typographicae, 1877), III (1553-1571) (Zagreb: Officina Societatis Typographicae, 1880); EUGENIO ALBERI, Le relazioni degli ambasciatori veneti al Senato durante il secolo decimo sesto, III, part 3 (Florence: Societa Editrice Fiorentina, 1855); MARIA PIA PEDANI, Relarioni di ambasciatori veneti al Senato. Costantinopoli (1512-1789), XIV (Padua: Bottega d'Erasmo - Aldo Ausilio editore, 1996).

22 Archivio di Stato di Venezia (State Archives of Venice, ASVe henceforth), Senato Deliberazioni Mar (SDM henceforth). The entire series limited to the years 1500-71, for both the registers and the filie (archival series).

23 ASVe, Senato Deliberazioni Secrete (SDS henceforth). The entire series limited to the years 150071 , for both the registers and the filze.

24 ASVe, Bailo a Costantinopoli (BaC henceforth), busta (envelope, b. henceforth) 264, 363, 365.

${ }^{25}$ ASVe, Lettere e scritture turchesche (LST henceforth), filza (fl. henceforth) 1-2.

26 ASVe, Capi de Consiglio de’ Dieci, b. 266, 279, 280, 281, 282, 283.

27 ASVe, Consiglio de' Dieci, Collegio. Lettere secrete, b. 15, 21, 22, 23, 24, 25.

28 ASVe, Commemoriali, registro (register, reg. henceforth) 21, 22, 23.

${ }^{29}$ ASVe, Avogaria di Comun, b. 3583.

30 ASVe, Senato Deliberazioni Costantinopoli (SDC henceforth), reg. 1, 2, 3 and fl. 1, 2.

31 ASVe, Miscellanea materie miste e notabile, b. 33.

32 State Archives of Zadar (SAZ henceforth), Opčina Trogir, b. 4-9.

33 SAZ, Opčina Šibenik, b. 7, 8, 36.1, 65, 70, 74, 85. 
various other files of public notaries. Since the Uskoks are even more present in the Venetian documents than the Morlachs, in the current stage of the research I used the same archival fonds researched for the Morlachs. However, since the period of focus preceded the War of Cyprus (1570-1573) and the War of Gradisca, also known as the Uskok War (1615-1617), my aim was to analyse the relations between them and the Morlachs, but more importantly the outcomes of these relations on the Venetian-Ottoman collaboration on the Dalmatian border.

The analysed documents are mainly letters exchanged between the central and regional authorities, ${ }^{35}$ complaints of Venetian subjects from Dalmatia and Istria, and official decisions taken by the Venetian Senate and sent for their application to its representatives in Dalmatia. Additionally, I identified some references in letters and agreements issued in various contexts regarding life on the border of Dalmatia and encounters with the Ottoman Empire. These documents were part of the correspondence among Venetian officials, whose main objective was to find solutions to the problems caused by the Morlachs or to answer some of their needs. In very few cases were these documents addressed directly to the Morlachs or written on their behalf. In these cases, a translation was mentioned, but without offering any details regarding the language from which it was made. Moreover, we lack sources issued by the Morlachs describing themselves or their origins. Given all these aspects, I chose to use the term 'Morlach' exclusively in line with the Venetian way of identifying them.

Therefore, out of 350 unpublished documents ${ }^{36}$ transcribed from various archival collections covering the period between 1500 and 1600, only 167 explicitly contain the term 'Morlach' in either of its forms (Morlacchi or Murlachi). ${ }^{37}$ The rest of the documents are relevant for different case studies in which a specific Morlach activity was the reason for the intervention of the Venetian authorities. Furthermore, from these 167 documents, 84 do not offer any explanation of the term 'Morlach,' appearing simply as an identifier for those involved in some dispute, commercial exchange or negotiations for the border. A further 35 documents mention the

34 SAZ, Zadarski Knez, Antonio Crivan, Antonio Michiel, and others.

35 Monique O'Connell, Men of Empire: Power and Negotiation in Venice's Maritime State (Baltimore, MA: The John Hopkins University Press, 2009), p. 2: 'Charged with putting Venetian state policies into practice, the Venetian rector played an essential mediating role, acting as the main face of Venetian rule for subjects and as the primary conduit of information, demands, and requests to and from the city.'

36 This analysis was made on the documents used for my $\mathrm{PhD}$ thesis. Hence, it only represents a part of the documents collected from the archives. This is why this sample just aims to emphasise their diversity and to set out some working hypotheses for verification.

37 Archivio di Stato di Venezia ASVe, LST, fl. 1-2: September 1528: 'murlacchi, quail transmigrano di loco in loco'; ASVe, SDM, reg. 61, carta (sheet, c. henceforth) 63v-64r: January 1540: 'quando che li Murlachi, che nella passata Guerra turchescha si leverono dal Banadego et venero ad habitar li territorii nostri'; ASVe, SDC, reg. 2, c. 21r-v: March 22, 1561: 'per la venuta a quella porta delli nuntii mandati dalli morlachi che sono in le ville 33'; ASVe, BaC, b. 365: 1553: 'et che li Morlacchi vengono l'inverno con li loro animali a pascolare [...] li Morlachi voleno combatter con loro et gli batteno et alle volte feriscono.' 
Morlachs as Ottoman subjects - morlacchi sudditi turchi $-{ }^{38}$ displaying the extent to which the Venetian authorities were also aware of the distinction between the Morlachs and other 'communities' present in Dalmatia. ${ }^{39}$ Most of these documents make a clear distinction between the Morlachs and the Uskoks (even though in some cases, like the document from 1570, they are described as the same group), ${ }^{40}$ the people of Dalmatia, Greeks, Gypsies ${ }^{41}$ and others. The same documents also offer possibilities of identifying the Morlachs as Christians, foreigners, ancient Hungarian settlers ${ }^{42}$ and in only one case as Vlachs. ${ }^{43}$ The latter aspect, however, can be quickly explained: the term 'Vlachs' only appears in the Venetian documents when the document is a translation of an Ottoman one. Thus, the discussion revolves around the how the Ottoman authorities understood this term: was it ethnic or social? ${ }^{44}$

As an example of a source for the Uskoks, it is worth adding a 56-page collection of 295 résumés of documents making reference to them. Kept in one of the registers of the Miscellanea ${ }^{45}$ fonds in the Venetian archives, this collection brings together information from collections like Stato da Mar, Senato Secreta, Dispacci a Costantinopoli and Bailo a Costantinopoli, covering the time frame between 1529 and 1576. It proves to be a very useful tool when trying to follow the outcomes of decisions made by the Venetian central authorities, regional officials, the Sultan, the Ottoman provincial authorities and occasional ambassadors, all of which deal with damage caused by the Uskoks.

To all of these we can add numerous male and female names accompanied by the term 'Morlach.' These types of documents are more common in the State Archives of Zadar and once more stress the fact that these terms were rather an identifier for individuals originating outside the Venetian lands and jurisdiction. Some examples of Morlach names can be selected from those mentioned by the documents kept in box number 7 of the Opčina Trogir collection from the State

38 ASVe, SDS, reg. 59, c. 93v-94r: October 22, 1538: 'la laudabil operatione per voi fatta de condur dalla obedientia dei Turchi alla devotion nostra quelli subditi Turcheschi della Murlaccha con li figlioli, donne, animali et altri beni soi'; ASVe, SDS,fl. 27: January 24, 1555: 'che sono menate via da uscochi 22 anime de morlachi subditi di quell Serenissimo Signor’; ASVe, SDC, reg. 3, c. 97v-98v: February 12, 1568: 'l'omicidio di dui murlachi sudditi turcheschi.'

39 ASVe, SDM, reg. 20, c. 126v-127r: 'per li proveditori nostril alla camera del'armament siino conducti alli stipendii de la Signoria Nostra galioti numero 3000 delle sotto scripte nationicione histriani, dalmatini, schiavoni, murlachi, albanesi et greci exceptuati quelli delle insule nostre di Candia et Cypri et Corphu.'

40 ASVe, SDM, reg. 39, c. 338v: February 6, 1570: 'che da quell rettor nostro siando condotti scochi overo Murlachi ducento con doi capi della loro natione.'

${ }^{41}$ ASVe, SDS, fl. 27: 'ladri uscochi vestiti in habito musulmano [...] assaltarono doi musulmani [...] et doi murlachi et una morlacha [...] essendo venuti alcuni Cingani.'

42 ASVe, Capi del Consiglio dei X, b. 281: 'nostra gens bellica Uschochi nominati in civitate Segnensi, [...] qui alias Murlachi nomine, sed re ipsa veters coloni Ungarorum sunt.'

43 ASVe, BaC,b. 365:'et in loro ville et castelli et luochi li huomini detti Vlachi veneno la invernata con le loro bestiame et castroni loro a pascolare.'

${ }^{44}$ Vjeran Kursar, 'Being an Ottoman Vlach: On Vlach Identity(ies): Role and Status in Western Parts of the Ottoman Balkans (15th-18th centuries),' OTAM 34 (2013): 115-61.

45 ASVe, Miscellanea, b. 123. 
Archives of Zadar: Milos Murovlachus de Bristiviza (July 15, 1549); Johannis Vesselicich murlaco di Succhidol (SuhiDol; April 2, 1569); Milan Murlaco di Petrovopoglie (April 19, 1569); Simeon Juanovich murlacus (April 20, 1569); Score Bracoevich (April 21, 1569); Jacomo Bascich murlacho de villa Triloque (Trogir hinterland; April 26, 1569) and many more.

\section{The Morlachs and Uskoks through Venetian Eyes}

The arrival of the Ottomans in the proximity of Venetian Dalmatia (after the conquest of Bosnia in 1463) diversified the contexts in which the Morlachs crossed the border, by both increasing the number of immigrants and encouraging commercial exchanges between the subjects. The negotiations for the border between the Republic of Venice and the Ottoman Empire in the mountainous area of Dalmatia started after the end of the 1499-1503 war. ${ }^{46}$ Since the powerful neighbour could not be driven away, the need to establish clear borders and rules to cross them became apparent. Before the beginning of a new war in 1537, Venice signed four agreements with the Ottomans. ${ }^{47}$ Accordingly, they solved the border issue as follows ${ }^{48}$ the subjects of the Sultan were forbidden to cross the border or to cause damage in the Venetian lands, and a similar prescription was valid for the Venetian subjects. This formulation was echoed in the regional officials' task to negotiate and draw the border, efforts carried on until the beginning of the Cyprus War and summed up in documents by the phrase per vicinar bene.

In this context, the Morlachs played a very important role, since they were the ones who kept the misunderstandings alive regarding the possession of some villages of mainland Dalmatia. The sources mention 33 villages in the hinterland of Šibenik and 3 in that of Trogir, inhabited by the Morlachs, ${ }^{49}$ Ottoman subjects, even though

${ }^{46}$ Bernard Doumerc, 'L'Adriatique du XIII ${ }^{\mathrm{eme}}$ au XVI ${ }^{\mathrm{eme}}$ siècle,' in Histoire de l'Adriatique, ed. PIERRE CABANES (Paris: Éditions du Seuil, 2001), 283.

47 Between 1503 and 1537 the following Venetian-Ottoman agreements were concluded: in 1503, Instrumentum Reciprocum published in HANS PETER ALEXANDER THEUNISSEN, 'Ottoman-Venetian Diplomatics: The ${ }^{\mathrm{c}}$ Ahd-names. The Historical Background and the Development of a Category of Political Commercial Instruments Together with an Annotated Edition of a Corpus of Relevant Documents,' EJOS 1, no. 2 (1998): 377-92; in 1513, capitulation in THEUNISSEN, 'Ottoman-Venetian Diplomatics,' 394-99; in 1517, capitulation in THEUNISSEN, 'Ottoman-Venetian Diplomatics,' 40014; in 1521, capitulation in THEUNISSEN, 'Ottoman-Venetian Diplomatics,' 415-36.

48 Even if attempts for a clear border demarcation were made, the sources suggest that they were not implemented until after the War of Cyprus. See WALter PANCIERA, 'Building a Boundary: The First Venetian-Ottoman Border in Dalmatia, 1573-1576,' Radovi: Zavod za hrvatski povijest 45 (2013): 9-37; WALTER PANCIERA, 'La frontiera dalmata nel XVI secolo: fonti e problemi,' Società e Storia, 114 (2006): 783-804; Walter Panciera, 'Tagliare i confini: La linea di frontiera Soranzo-Ferhat in Dalmazia (1576),' in Studi storici dedicati a Orazio Cancita, eds ANTONINO GIUfFridA, FABrizio D'AVENIA and DANIELE PALERMO (Palermo: Mediterranea, 2011), 237-72.

49 Some disputed villages also came under discussion in the hinterland of Zadar, but the Morlachs were not 'blamed' for it. For the villages from Šibenik and Trogir, see also KriSTIJAN JURAN, 'Doselavanje Morlaka u opustjela sela šibenske Zagore u 16. Stoljeću,' Povijesni prilozi 46 (2014): 129_ 60; Cristian LuCA, 'The Vlachs/Morlaks in the Hinterlands of Traù (Trogir) and Sebenico (Šibenik), Towns of the Venetian Dalmatia, During the 16th century,' in Miscellanea bistorica et archaelogica in honorem Professoris Ionel Cândea (Brăila: Istros-Muzeul Brăilei, 2009), 311-22; SNJEŽANA BuZOV, 'Vlaška 
the villages were in Venetian territory, according to previous documents. ${ }^{50}$ A résumé of the negotiations for the borders and villages of Sibenik is contained in a description $^{51}$ written sometime between 1566 and 1568. The author, thought to be Francesco Difnico/Franjo Difnić, paid special attention to the villages from this hinterland occupied by the Morlachs after the Ottoman conquest of Skradin (1522). The villages, abandoned by the Venetian subjects ${ }^{52}$ who were driven away by fear of the Turks, attracted Ottoman subjects willing to exploit their resources. The discontent of the rightful owners was obvious and discussions for the release of the lands could not be avoided, creating a situation that lasted at least until the beginning of the Cyprus War.

But the Morlachs were not only illegal settlers in Venetian villages. They also became immigrants and benefited from a special status in the Venetian lands, stimulating Venice to develop an official settlement policy. Usually, the main aim of this policy was to transfer the immigrants to Istria and grant them lands and some exemptions in exchange for populating and working these abandoned areas. The solution was administrative in nature, since Istria was being drained of its population, while Dalmatia had become too crowded with immigrants and individuals entering to plunder the place. This overpopulation of Dalmatia was solved by the transfer of people to Istria. Obviously, the decision was also influenced by the fact that the new arrivals did not respect the rules or laws of Venice or fulfil their status as guards of the border against the Ottomans, their former lords. When these inconveniences happened in Istria, it became a matter of internal administration..$^{53}$ Over time, as the higher stability of Istria managed to influence the Morlachs, some changes could be seen. Without a direct Ottoman influence, and having agricultural fields, markets to sell their products and authorities to assure their protection, the Morlachs began to act as subjects of the Venetian state.

The same evolution was not enjoyed by the morlacchi istrian $;{ }^{54}$ the name we find in the sources for the Morlachs who settled in the hinterland of Zadar during the war of 1537-1540. This case study offers a singular example concerning the Dalmatian

sela, pašnjaci i čifluci: krajolik osmanlijskog prigraničja u šesnaestom e sedamnaestom stoljeću,' in Triplex Confinium (1500-1800): ekohistorija, eds DRAGO ROKSANDIĆ et al. (Split/Zagreb: Hrvatsko Povijest Filozofskog Fakulteta Sveučilišta u Zagrebu, 2003), 227-41.

50 A relevant example is the list of documents written by Daniele di Ludovico in July 1531 which contains more than ten documents issued by the kings of Hungary, Bosnia, or other powers in the Western Balkans. He created this list to help the negotiations for the border of Dalmatia and to prove that the villages from the hinterland of Šibenik and Trogir counted among the Venetian possessions. ASVe, LST, fl. 1-2.

51 ŠIMEOn LJubIĆ, Commissiones et relationes Venetae, III (1553-1571) (Zagreb: Academia Scientiarum et Artium Slavorum Meridionalium, 1880), 238.

${ }^{52}$ LJUBIĆ, Commissiones et relationes Venetae, 239.

53 See Tomaso Caenazzo, 'I Morlacchi nel territorio di Rovigno,' in Atti e memorie della Società Istriana di archeologia e storia patria, 1(1885), 129-40; LIA DE LUCA, Venezia e le immigrazioni in Istria nel Cinque e Seicento (PhD thesis, University Ca' Foscari, Venice, 2011).

54 SILVIA-Dana CACIUR, 'Migrații spontane și organizate în teritoriul Zarei (Zadar-ului) la mijlocul secolului al XVI-lea. Cazul Morlacilor Istrieni,' Studii și materiale de istorie medie 34 (2016): 73-104. 
hinterland and Venetian involvement in convincing the Morlachs to settle in its jurisdiction and including them in the provinces' administrative system. The evolution of this community during the sixteenth century opens the possibility of analysing a set of features which allow an understanding of the Morlachs' transformation from an ethnic group into a social one. This transformation took place without excluding features specific to the ethnic groups and indeed occasionally they could be observed inside the larger social group. As subjects of the Serenissima and new settlers, they enjoyed various privileges and exemptions. Three decades after their settlement in the Venetian lands, in $1569,{ }^{55}$ the benefits they had received in 1538 were reconfirmed and their exclusion from service on the galleys was extended. However, the Morlachs wished to be included among the troops active in Dalmatia and to receive a salary for defending the lands from thieves and the incursions of the Ottoman soldiers. In the beginning, the Senate refused their request, since all the privileges they had received were granted to them in order to cultivate the lands and to defend the inner parts of Dalmatia. However, their inclusion in a more organised system of defence seemed to be a good idea. Accordingly, the official decision was to hire two Morlachs in larger companies of Croatian soldiers, and one in the smaller ones, with the possibility of hiring more once positions became available. The salary was similar to that paid to the Croatian soldiers. Interestingly enough, in their request, recapitulated and presented in Venetian dialect by the regional Venetian officials, the Morlachs asked to receive the same status and salary as was granted to the Levantines, since they too were loyal subjects who left their houses and lands and chose to live in the shadow of the Serenissima. It shows their awareness of their advanced stage of assimilation within the rules and practices of the Venetian state.

However, the Morlachs of Dalmatia continued to cross the Venetian-Ottoman border the way for which they were best known: as shepherds. Shepherding and a semi-nomadic transhumance practice were specific activities that came with an implicit lifestyle, connected through many common elements with the shepherding traditionally attributed to the Vlachs spread all over the Balkan Peninsula, and to the north up to southern Poland. ${ }^{56}$ Nevertheless, the role played by transhumant shepherding in the survival of an ethnic group in the Balkans has to be questioned. The research required for a history of the Morlach shepherds has to be, in first place, linked to the socio-political changes of the areas they roamed and then the ethnicity this practice might suggest.

Unfortunately, the Venetian sources neither allow us to establish whether the Morlachs were exclusively shepherds, nor argue that all the Morlach shepherds were exclusively Vlachs, even though they are nevertheless connected with the Vlach shepherds from the inner Balkans. In Dalmatia, the Morlach shepherds could be

55 ASVe, SDM, fl. 43.

${ }_{56}$ Miloš LuKOviĆ, 'Self-government Institutions of Nomadic and Semi-nomadic Livestock Breeders in the Balkans and in the Carpathian Regions in the Late Medieval and Early Modern Periods,' Res Historica 41 (2016): 51-94; and others. 
encountered during the winter months, between November and April. For these six months the Morlachs used the fields of the locals to feed and water their flocks. Since no mention of reserves of hay is found in the documents, it is clear that the public or rented pasture lands, or those situated far from the towns were not enough to feed the flocks. The case of the water sources was similar. Also, in the months spent in Dalmatia, the Morlach shepherds used to conclude commercial collaborations or rent land, thus creating bridges for cultural exchanges, if necessary. ${ }^{57}$ Pastoral transhumance proved to be another element that allowed the Morlachs to adapt to different political systems. The transformations caused in Dalmatia by the Venetian-Ottoman neighbourliness regime at the same time facilitated the survival of a traditional way of life and increased their integration in Dalmatian society.

While far from being a predominantly mercantile 'community, ${ }^{58}$ the Morlachs nevertheless developed some dynamic commercial activities in Dalmatia. They crossed areas difficult to cross and connected communities from both sides of the mountains. This trade involved skilful individuals familiar with the opportunities granted by the different geographic spaces. It can be assumed that the involvement of Morlachs in these commercial activities might testify to the presence of a richer stratum of these people, much more open to assimilation in the lowland communities. Since these journeys from the inner Balkans towards the coastal towns were quite frequent, it can be concluded that the Morlachs were familiar with the customs and rules of the markets. Accordingly, they had to respect them in order to exploit the opportunities for their own interests.

These aspects are mostly visible when analysing the commerce of cereals brought from the Ottoman territories. This commerce was a constant part of the Morlachs' trade, although it easily became subject to smuggling especially after the Sultan's decision to stop exports. ${ }^{59}$ Nevertheless, the Morlach caravans carrying cereals into the Dalmatian towns and buying salt were emblematic in identifying their traditional role.

Opportunism defined the Morlachs' commerce in Dalmatia. The need to sell the excess products obtained from grazing sheep led to their specialisation and

\footnotetext{
${ }^{57}$ For more about these see DANA CACIUR, 'Considerations Regarding the Status of the Morlachs from the Trogir's Hinterland at the Middle of the 16th Century: Being Subjects of the Ottoman Empire and Land Tenants of the Venetian Republic,' Res Historica 41 (2016): 91-110.

58 A good example of such a type of mountain and pastoral community, but clearly defined in ethnic, social and geographic terms, is presented in PATRICE POUJADE, Une société marchande. Le commerce et ses acteurs dans les Pyrénées modernes (Toulouse: Presses Universitaires du Mirail, 2008).

59 MARIO GRIGNASCHI, 'Les documents ottomans conserves aux archives de la maison d'Este à Modena,' in Türk Tarih Kongresi 9, no. 2 (1981), doc. no. 11, p. 825: Commandamento [...] sopra la sublime curia [...] tratta delli formenti per foura del regnio ai di 15 del ramazan 962, cioe ai di 21 d'agosto 1555; BRUNO SIMON, 'Contribution à l'étude du commerce vénitien dans l'Empire Ottoman au milieu du XVIe siècle (1558-1560),' Mélanges de l'École française de Rome, Moyen Age, temps modernes 96, no. 2 (1984): 9731020 .
} 
identification as the main providers of significant quantities of cheese, ${ }^{60}$ wool, sheep, lambs and leathers. This traditional practice developed in a context where the demand for subsistence products increased in Dalmatia, while Venice, on the other hand, did not show a direct interest in the Morlachs' goods (they were only sent to Venice through the mediation of local merchants who used to sell Dalmatian products together with other local items). As a result, the Morlach trade became an advantageous activity for all the parties involved without monopolising the economic life of Dalmatia.

Nevertheless, the Morlachs were far better known as malefactors, merciless cold-blooded outlaws and public enemies. A narrow province under constant pressure of war and populated by many different 'out-comers' forced the authorities to solve each case of criminality in order to avoid an escalation of the conflict. The Morlach outlaws can be only considered examples of banditismo up to a certain point, ${ }^{61}$ especially since their actions did not emerge from some form of sanguine malevolence, but as a solution for survival in merciless conditions. However, there were many aspects that might convince us to speak about the sixteenth-century Morlachs as bandits. Suffice it to mention the highway thefts, killings, kidnappings that fed the slave markets, rapes and animal stealing, together with cases of complicity with local authorities, traditional forms of justice (the vendetta) and close ties with their milieu of origin (i.e., the community to which the leader belonged). ${ }^{62}$

In fact, when discussing crimes involving the Morlachs some important distinctions can be observed between the outlaw inhabitants of the Venetian lands and the malefactors arriving from the Ottoman territories. This distinction is relevant because it justified the different measures applied by Venice in order to react to or stop disruptive events. It can be noticed that when the outlaw Morlach was a Venetian subject (a colonised subject in a settlement under Venetian administration), his punishment involved a public announcement to appear before a court of justice. ${ }^{63}$ If a number of days passed and he did not arrive, then he was banished from all Venetian territories and ships, with an attractive reward for those willing to offer information about the criminal. This form of punishment, the banishment of a criminal, was defined by Venetian laws under the term of bando (Medieval Latin

${ }^{60}$ Florence SABIne FABIJANEC, Le développement commercial de Split et Zadar aux XVe-XVTe siècles: Un commerce transitaire entre l'Europe et la Méditerranée (Saarbrücken: Éditions Universitaires Européennes, 2011); SAZ, Opčina Šibenik, b. 70: fragment of a customs register containing large quantities of Morlach cheese shipped to Venice in the year 1576.

${ }^{61}$ Neva Makuc, 'Noble Violence and Banditry along the Border between the Venetian Republic and the Austrian Habsburgs,' Mediterranea: Ricerche storiche 12 (2015): 211-226, see 212.

${ }^{62}$ Considering the aspects defining a bandit as established by ERIC HOBSBAWM in Bandits (ABACUS, 2000). It is worth considering that the author stressed the fact that all bandits had a pastoral origin, like in the case of the Balkan hayducs, and that they benefited from an autonomy granted by a traditional lifestyle, by their past and the geographic area they originate from.

63 ASVe, SDM, reg. 25, c. 173r-v: Antonio Carlich Murlacho and his companions carried out some acts of violence and robberies in the summer of 1540 , one of them ending with the death of a soldier/knight at the service of the captain of Raspo. 
bannum). It can be found among the capital punishments, together with the death penalty, life sentence or forced service as a rower on the Venetian galleys for a specific amount of time. ${ }^{64}$ On the other hand, when the Morlach offender was an Ottoman subject, his punishment was negotiated with the Ottoman representative who had the right to judge him. ${ }^{65}$

It appears there was a clear distinction drawn between incursions for plunder and occasional incidents caused by the Morlachs. Venice had to deal with Morlach criminality in a different way and to find specific solutions in order to transform the damage into advantages or at least to diminish it. The mentioned differences emphasise the specifics of the Morlach communities (always ready to fight but attached to the family) as well as the ways followed by Venice to protect the border and to solve the demographic challenges. ${ }^{66}$ The settlement of a few thousand Morlachs $^{67}$ for the entire time frame of my research is a clear answer to these permanent problems of Venetian Dalmatia.

As suggested at the beginning, the sources mentioning the Morlachs are rather short and lacking in detail. They are almost exclusively Venetian and record the Morlachs' activities in contexts that challenge the good administration of the province. While the peace agreements between the bigger actors may have settled the ideal relationships, the everyday encounters at the local level were more about threatening the desired peaceful coexistence. In a region like Dalmatia, threatened by the Ottoman military offensive towards the Adriatic, the Morlachs appeared as nothing more than another potential reason for conflict. Therefore, from the Venetian perspective, the Morlachs were those people who arrived in Dalmatia from beyond the mainland border; they were shepherds, merchants, malefactors, immigrants, colonists, soldiers, etc. While a Morlach or a group of Morlachs could engage in one or more of these activities, what was certain is that they originated from beyond the border of Dalmatia. Aspects like religion, language and ethnicity (in a modern sense) cannot be derived from the analysed sources, which are mainly administrative in nature and grant no significance to such details.

${ }^{64}$ EDOARDO RUBINI, Giustizia veneta. Lo spirito Veneto nelle leggi criminali della Repubblica (Venice: Filippi Editori, 2010), 99-100; MAKUC, Noble Violence,' 214: 'the characteristic practice of the Venetian authorities [was] sentencing criminal offenders to banishment. The most severe penalty was a bando capitale, which meant that anyone had the right to kill an exile with impunity.'

${ }^{65}$ Some other examples can be found in DANA CACIUR, 'Soluțiile oficialilor venețieni din Dalmația la practicile criminale ale morlacilor în decursul secolului al XVI-lea. Cazul: Milia Popovich/Melia Popović', in Povestiri întretăiate.Istoria în cheie minoră, ed. OvIDIU CRISTEA (Târgoviște: Cetatea de Scaun, 2016), 295-314.

66 This was even more important since there were Venetian subjects willing to go into the Ottoman lands and become Muslims and subjects of the Sultans. See KLEMEN PusT, "Le genti della citta, delle isole e del contado, le quale al tutto volevano partirsi." Migrations from the Venetian to the Ottoman Territory and Conversions of Venetian Subjects to Islam in the Eastern Adriatic in the Sixteenth century,' Izvorni znanstveni rad 40 (2011): 121-59.

${ }^{67}$ ANGELO DE BENVEnUti, Storia di Zara dal 1409 al 1797 (Milan: Fratelli Bocca editori, 1944), 106. 
In addition to all of these already complicated aspects of the Morlachs' identity, we have to mention their relations with the Uskoks. They are relevant mainly because they give even more emphasis to the status of the Morlachs as inhabitants of the border, or marginal people. As Ottoman subjects, and tolerated by the Venetians, the Morlachs became easy victims of the Uskoks, who were in charge of sabotaging the Ottoman offensive. By attacking, kidnapping, killing or robbing the Morlachs, the Uskoks threatened the Venetian-Ottoman relations ${ }^{68}$ and affected the commercial agreements and border negotiations.

Officially in charge of protecting the Habsburg border in the south of Dalmatia, after 1537 the Uskoks settled in Senj/Segna and its hinterland. Having fought against the Ottomans, the Uskoks became a constant source of tension and conflict between Venice and the Sublime Porte in spite of their agreements regarding the rule of the Adriatic. The piracy or corsair activities of the Uskoks increased in frequency over the sixteenth century and challenged the task of Venice to protect the sea and the maritime commercial routes, as established in the Venetian-Ottoman agreement from 1540. ${ }^{69}$ However, the Uskoks' attacks were also organised in the inner parts of the Venetian over-sea province, especially but not exclusively in Northern Dalmatia. From this point of view, an investigation into the Uskok raids on Ottoman subjects crossing the border region of Dalmatia opens new research directions regarding the relations between the regional and central authorities of the three states involved. Moreover, it creates the opportunity to examine new elements defining the various social groups present in the rural hinterland of Dalmatia.

A very important aspect of this Morlach-Uskok relationship is shaped by the dynamism of their interaction. In most Venetian documents, the Morlachs appear as victims of the Uskoks, ${ }^{70}$ even though they were equally protected by the Venetians and the Ottomans. ${ }^{71}$ The Uskoks were depicted as the main enemies of the Ottomans, Morlachs and Venetians. However, certain sources reveal that the Morlachs, and others besides, ${ }^{72}$ frequently helped the Uskoks in organising plundering raids and received a share of the loot. Morlachs also left the Venetian lands and chose the Uskok lifestyle, especially to flee Venetian justice or to enjoy an

${ }^{68}$ BRACEWELL, The Uskoks of Senj, 187-89.

69 TOMmaso STEFINI, 'Irregolarità e rapporti di forza nella Dalmazia del Cinquecento,' Studi veneziani 59 (2010): 634.

70 ASVe, SDS, fl. 20: February 20, 1545: 300 Uskoks attacked Morlach shepherds, Ottoman subjects in the hinterland of Šibenik; ASVe, SDS, reg. 59, p. 58v-59r: October 29, 1554: 14 Uskoks dressed in Ottoman clothes (vestiti in habito Musulmano) kidnapped three Morlachs, two men and one woman, to sell them as slaves in Segna; ASVe, SDC, fl. 1: November 1558: 18 Morlachs, sudditi turcheschi, were taken by the Uskoks to be sold as slaves in Segna; etc.

${ }^{71}$ Sometimes they even collaborated to rescue the Morlachs: ASVe, Libri Commemoriali, reg. 22, c. 100v-100r: in the winter of 1546-1547 eight Morlachs, men, woman and young boys, and one Turk, Ferhat, were recovered from the Uskoks by the joint efforts of Paulo Giustinian, captain of fuste, Stephano, the son of the former count and captain of Šibenik and Rezep, the Ottoman emino living in Sibenik.

72 ASVe, SDM, fl. 25: 'uno Gregorio Cernarich complice participe de Uschochi nella casa del quale se dividevano le prede.' 
easier life based on plunder. In all these cases, the Venetian authorities had to intervene in order to recover the Morlachs or their goods, to catch Uskoks who had killed Morlachs, or to protect the Morlach caravans from Uskok raids in Venetian lands. ${ }^{73}$ It is clear why the Venetians resented their presence and denounced the actions of the Uskoks, usually referring to them with aggressive words.

The Uskoks found a place in the history of the Balkan world as a social group on which the ruling state did not apply any coercive measures, instead exploiting their 'abilities' to secure a fragment of the border with the Ottomans. The Habsburg masters granted them military freedom in exchange for the defence of a triple border $^{74}$ in a high mountain area. Like the Morlachs present in the Venetian territories who were tolerated, encouraged and hardly punished for their misconducts, the Uskoks who settled in the Habsburg lands appear as a marginal autonomous people who were in fact a useful instrument in the hands of the state. Two aspects of a world marked by war, the Morlachs and the Uskoks are relevant examples of marginal people managing to carry on a traditional lifestyle while developing strong connections with the ruling powers.

\section{Conclusions}

In the sixteenth century, the hinterland of Venetian Dalmatia became a place where 'the others' - that is, refugees from the territories affected by war ${ }^{75}$ - had to adapt to the rules of the locals and to find ways to maintain their specific cultural traits. At the formal level the Venetian administration made it clear that the border had to be respected; but, at the ground level, they did not exclude the coexistence of different subjects with the expressed intention to respect the pact of neighbourliness (buona vicinanza) and friendship with the Ottomans. The continuous immigrant waves caused the officials to find ways to integrate the newcomers and use this human resource to repopulate the region, to protect the borders and to revitalise agriculture in the areas affected by depopulation and Ottoman raids. In turn, the immigrants welcomed the opportunities offered: lands for houses and agriculture, exemptions from taxes and military duties, and the possibility of practising commercial activities in the region. They combined this new stability with their own lifestyle and created autonomous communities, with certain fiscal and military obligations.

Researching the Morlachs and their relations with other marginal populations, especially with the Uskoks, enhances our knowledge about these border people in the early modern period. Communities which are defined by great ethnic and

73 ASVe, SDS, reg. 65, c. 133r-v; ASVe, SDS, fl. 2: a Morlach caravan transporting salt from Šibenik was attacked by 40 Uskoks while crossing the mountains. According to the Venetians they were escorted by soldiers to the border, while the attack took place in the Ottoman lands.

74 See the studies published within the Triplex Confinium: International Research Project accessed November 11, 2020 http://www.ffzg.unizg.hr/pov/zavod/triplex/triplex_confinium_homepage.htm.

75 BORNA FUerst-BJELIŠ, 'Imagining the Past: Cartography and Multicultural Realities of Croatian Borderlands,' in Cartography: A Tool for Spatial Analysis, ed. CARLOS BATEIRA (Porto: IntechOpen, 2012), 295-312, see 299. 
professional diversity but offer scarce information about themselves demand historical research which delves into a large number of sources of various provenances. Nevertheless, they are a crucial source of information on border regions, often inhabited by lesser-known groups of people who have their own specific strategies for survival and adaptation. For certain situations, the analysed sources suggest a three-state approach when discussing these cross-border subjects. This is the case of the Morlach caravans that were protected by the Venetian strattioti while present in the Venetian hinterland and immediately attacked by the Uskoks after they entered the Ottoman territory. The same idea applies for those cases when the Morlachs or other Ottoman subjects chose to become Uskoks and to move to Habsburg territory. For this reason, while emphasising the relations between the Morlachs and the Uskoks in the Dalmatian hinterland, one should not ignore the role of diplomacy (regional and central) as it developed between Venice and the Ottoman Empire. Together with other factors of coexistence on the common border, the presence of the Uskoks and their interactions with the Morlachs (mainly Ottoman subjects) contributed to shaping the 'neighbourliness' policy. Therefore, research into these very active, mobile people extends the perspectives on Venetian-Ottoman relations by strengthening the visibility of some 'small actors' as true cross-cultural and transimperial agents. 